\title{
APENAS TRÊS FOTOGRAFIAS COTIDIANAS
}

\author{
Mitsi Pinheiro de Lacerda
}

Resumo

$\mathrm{O}$ artigo apresenta estudo que aborda, enquanto tema, a interface entre fotografia e vida cotidiana. $\mathrm{O}$ objetivo é buscar aproximações entre contribuições oferecidas por Roland Barthes e José de Souza Martins no que se refere à produção e uso da fotografia, e entre os delineamentos teóricos de Michel de Certeau e Henri Lefebvre, em relação à vida cotidiana. O método empregado foi a pesquisa bibliográfica, em concordância com orientações metodológicas e epistemológicas da faiscação. O artigo inicia por brevíssima introdução, seguida de seção dedicada à exposição do referencial teórico. A segunda seção trata da mostra e discussão de três imagens provenientes da vida cotidiana e precede a conclusão do texto. Os resultados e conclusões do estudo destacam aspectos da fotografia e da vida cotidiana associados à imprevisibilidade, criatividade, liberdade e autoria, observando usos contemporâneos da produção de imagens nas quais os cotidianos são registrados e expostos excessiva e publicamente, bem como ressaltando a relevância da fotografia que adentra um campo potente à consciência do outro.

Palavras-chave: vida cotidiana; fotografia; liberdade.

\section{ONLY THREE EVERYDAY PHOTOS}

\section{Abstract}

The article presents a theoretical study about the interface between photography and everyday life. The objective is to seek approximations between Roland Barthes and José de Souza Martins regarding the production and use of photography, and between the theories of Michel de Certeau and Henri Lefebvre, in relation to everyday life. The methods used were bibliographic research and sparking. The article starts by a brief introduction, followed by the first section, which is dedicated to the exposition of the theoretical reference. The second section deals with the exhibition and discussion of three images from daily life. Finally, there is the conclusion of the text. The results and conclusions of the study highlight aspects of photography and everyday life associated with unpredictability, creativity, freedom and authorship. It observes the contemporary uses of the production of images in which the daily ones are registered and exposed excessively and publicly. It emphasizes the relevance of photography that enters a powerful field into the consciousness of the other.

Keywords: everyday life; photography; freedom.

\section{SÓLO TRES FOTOGRAFÍAS COTIDIANAS}

\section{Resumen}

El artículo presenta un estudio teórico sobre la interfaz entre fotografía y vida cotidiana. El objetivo es buscar aproximaciones entre las contribuciones ofrecidas por Roland Barthes y José de Souza Martins en lo que se refiere a la producción y uso de la fotografía, y entre las teorías de Michel de Certeau y Henri Lefebvre, en relación a la vida cotidiana. Los métodos empleados fueron la investigación bibliográfica y la faiscación. El artículo se inicia por breve introducción, seguida por la sección que se dedica a la exposición del referencial teórico. La segunda sección trata de la muestra y discusión de tres imágenes provenientes de la vida cotidiana. Por último, la conclusión del texto. Los resultados y conclusiones del estudio destacan aspectos de la fotografía y de la vida cotidiana asociados a la imprevisibilidad, creatividad, libertad y autoría. Observa los usos contemporáneos de la producción de imágenes en las que los cotidianos son registrados y expuestos excesiva y públicamente. Resalta la relevancia de la fotografía que adentra un campo potente a la conciencia del otro.

Palabras clave: vida cotidiana; fotografía; libertad. 


\section{BREVÍSSIMA INTRODUÇÃO}

O artigo apresenta estudo no qual é estabelecida conversação com autores que se dedicam, dentre outras questões, à fotografia (BARTHES, 1984; MARTINS, 2008) e com autores que tomam a vida cotidiana enquanto um de seus interesses (CERTEAU, 1994; LEFEBVRE, 1986; 1991). O objetivo do artigo é buscar aproximações entre as contribuições oferecidas pelos teóricos e a mostra de algumas imagens da vida cotidiana. Os métodos utilizados foram a pesquisa bibliográfica e a faiscação (LACERDA, 2015, p. 50).

\section{A FOTOGRAFIA E OS COTIDIANOS}

Os privilégios usufruídos por aqueles que compõem um restrito grupo dominante estariam ameaçados se apenas o capital os assegurasse. A manutenção de sua distinção se consolida, também, através da produção da inexistência do outro (SANTOS, 2002b), seja confiscando, regulando, manipulando ou silenciando linguagens, crenças, corpos, práticas, conhecimentos, artefatos, espaços e tempos. Nesta ação avassaladora por domínio, nada escapa: o que não se presta a ser capitalizado, é convertido, menorizado, controlado. Hierarquias normatizadoras são estabelecidas por toda a parte. Elas definem sexualidades, religiosidades, comportamentos, a História, as culturas, relacionamentos, etnias, famílias, ocupações, corporeidades, papéis sociais e qualquer outra prática existente na vida cotidiana, manifesta por pessoas comuns. Qualquer gesto ou linguagem que não se enquadre na lógica hegemônica estabelecida pode ser levado a julgamento e se tornar passível de medicalização ou apagamento - inclusive a Ciência. Tudo isto se passa em 2020.

Nunca imaginei que um dia escreveria algo assim. É que cheguei a supor que a ocorrência simultânea e contínua de orientações fascistas já havia sido devidamente denunciada, e que algo havia se modificado. Cheguei a acreditar que as lutas que nos antecederam haviam esboçado uma sociedade que nos caberia expandir; que as mazelas ainda presentes já haviam sido descritas e que a continuidade da luta seria suficiente. Hoje seria dia de conhecer e oferecer visibilidade a currículos que jorram ininterruptamente desde as relações pedagógicas e sociais, seria dia para inventarmos modos de usar a avaliação a favor do ensinaraprender, seria o momento ideal para nutrir sentidos presentes na alfabetização e também para admirarmos o início da transformação social após o reconhecimento de culpas históricas que são nossas - mas aqui estamos, hoje, retomando questões já amplamente discutidas e refutadas. Não retornamos ao passado, pois fisicamente isso não é possível, mas descuidamos do fato de que os tempos históricos coexistem através da persistência de concepções oriundas de diferentes épocas (LEFEBVRE, 1986). Hoje aprendemos, na dor, que não é suficiente denunciar, criticar, refutar, mas que é preciso lutar e educar permanentemente e botar reparo no mestre maior - Paulo Freire - que insistia acerca do trabalho de conscientização, este tão abandonado desde os recentes momentos de liberdade que vivemos. Estamos diante de um palimpsesto e alguém raspou o pergaminho iluminando, novamente, o que ingenuamente nos parecia soterrado.

Atualmente, as políticas neoliberais adentram os mais diversos níveis, abrindo caminhos para retrocessos com o crescente favorecimento dos favorecidos, a diminuição e/ou precarização dos serviços públicos, o investimento no crescimento econômico e o sucateamento do desenvolvimento social. Junto a isso, a vida cotidiana também é violentamente invadida através da avaliação recrudescida dos modos de existência e de tudo o que acontece nas relações humanas. E por que os dominantes avançam nas vidas cotidianas de pessoas comuns e não se limitam a sobrepujar o que se passa no âmbito político e econômico superior? Por que se dispõem a observar e governar as mais ordinárias práticas? 
Na última década, o corpo começava a correr pelas tramas da inventividade... A diferença se expandia em sentidos tão complexos que não podia mais ser nomeada... A palavra acontecia em universos criativos e este país avançava na delícia de práticas de liberdade e instituintes. Anteriormente restrita a um grupo economicamente favorecido, as práticas culturais de produção de imagens foram popularizadas, e um turbilhão de movimentos cotidianos foi registrado por uma infinidade de autorias que os comunicou publicamente. O beijo, o alimento, a festa, as relações sociais, a alegria, a dor - a vida abandonou sua restrição privada e jorrou ininterruptamente, explicitando a riqueza dos cotidianos.

Isso fez com que a hegemonia neoliberal avançasse desde níveis inalcançáveis à população, até as frestas mais singulares de sua existência. Através de imagens que registram a vida cotidiana, entregamos aos dominantes um vasto conhecimento acerca de quem somos e isto fomentou diversas entradas para a opressão. Hoje não somos tão somente reféns de políticas que usurpam os direitos sociais, mas também somos alvos de projetos que visam converter relações sociais em relações sociais de produção (LEFEBVRE, 2000).

$\mathrm{Na}$ atualidade, portanto, a população se encarrega de produzir e comunicar (em grande parte, publicamente) diferentes linguagens que dão a ver sua própria existência. É possível sugerir que cada vez menos temos caminhado sorrateiramente pelo campo do outro, empregando táticas e tendo o tempo como aliado na espera paciente pelo momento certo de agir - conforme aprendemos em Certeau (1994). Hoje a população se apresenta exibidamente no interior do campo do outro, replicando no interior deste próprio ${ }^{1}$ os modos de vida burguesa e utilizando a máscara do moderno (MARTINS, 1994). O elevadíssimo número de usuários que compartilham fotografias da vida privada em redes sociais atesta isso.

A fermentação das contradições se desdobra em realidades até então pouco conhecidas. A menina filha da classe trabalhadora sonha em se vestir de princesa e dançar uma valsa vienense em seu aniversário de quinze anos. Ela não conhece a dança do marabaixo. Enquanto na valsa os passos são largos e altivos, percorrendo todo o salão para marcar a liberdade e sofisticação de quem os forja, no marabaixo os passos são contidos e miúdos, e os pés praticamente não se distanciam entre si porque, originalmente, era uma dança praticada por negros escravizados, cujos pés se encontravam atados por correntes. Ao sonhar com a valsa e o vestido, a menina adentra um próprio - ao mesmo tempo em que utiliza a máscara do moderno. Para Martins (1994), esta máscara seria a avassaladora penetração dos elementos que sustentam a lógica dominante em todos os aspectos das vidas cotidianas de pessoas comuns. A impregnação desta máscara favorece a continuidade de um passado já conhecido, criticado e refutado. Tudo aquilo que já foi amplamente desvelado e rechaçado - a escravidão, a exploração, a evangelização - persiste no tecido social tanto porque são problemas históricos que não foram resolvidos, tanto porque os aspectos que os constituem permanecem nas práticas da atualidade. A menina não sabe que seus ancestrais dançavam marabaixo nos porões dos navios, com os pés sangrando, acorrentados, enquanto o homem branco bailava com sua senhora no salão. À menina não foram oferecidas lições escolares acerca disso, porque a história crítica da dança não dispõe de status para compor o currículo. Como, então, um modo de existência se torna hegemônico e objeto de consumo para uma população inteira?

A infinidade e diferenciação de respostas a esta pergunta estão presentes em todas as práticas e linguagens que se desdobram desde um pensamento crítico. Aqui podemos examinar,

\footnotetext{
1 Para Certeau, o próprio seria um lugar físico ou mentalmente delimitado, no interior do qual se configura o centro gerencial de um modo hegemônico de querer e poder. O próprio pode ser estabelecido por diversas instituições modernas, dentre elas as que envolvem a economia, a ciência, a política, a língua e a lógica militar. Embora caminhem no interior do próprio, aos praticantes do cotidiano não é permitido alterá-lo - por isso são permanentemente cobertos pela engenhosidade panóptica.
} 
rapidamente, um dos fatores que favorecem a persistência, na atualidade, de concepções e práticas provenientes de realidades anteriormente refutadas. Para Martins (1994, p. 14), esta persistência incorre no atraso que "[...] freia o processo histórico e o torna lento".

O que podemos destacar no processo de manutenção da hegemonia, neste momento, seria a produção e difusão de imagens acerca da vida cotidiana na contemporaneidade. Atualmente, os cotidianos são registrados em imagens, tornando a vida aparente e mais facilmente controlada. Os que dispõem de projetos de dominação sabem que a vida cotidiana é a vida de todos nós, e que é no cotidiano que nos encontramos, nos sentimos e, muito especialmente, inventamos alternativas para o que está posto. Para Lefebvre (1991a), a vida cotidiana acontece contraditoriamente em sua riqueza e miséria possibilitando a continuidade da existência, ao mesmo tempo em que aprisiona sua vitalidade ao tornar o espaço funcional, burocratizar as práticas e reproduzir o modo de produção no interior das relações sociais. Assim:

Lugar de equilíbrio, [a vida cotidiana] é também o lugar em que se manifestam os desequilíbrios ameaçadores. Quando as pessoas, numa sociedade assim analisada, não podem mais continuar a viver sua cotidianidade, então começa uma revolução. Só então. Enquanto puderem viver o cotidiano, as antigas relações se reconstituem (LEFEBVRE, 1991a, p. 39).

A exposição massiva dos mais recônditos aspectos da vida cotidiana através de imagens se tornou uma porta de entrada para a expansão do poder. Como dito anteriormente, é possível que o praticante do cotidiano esteja a minimizar sua astúcia milenar que o conduzia pelo interior de um próprio. Agora ele adentra este próprio utilizando máscaras que lhes são vendidas no mercado, e estas máscaras nada mais são do que réplicas de um projeto que há séculos o aprisiona. As máscaras sufocam, mas seu valor se incrementa a cada dia. E não basta ter a máscara e utilizá-la, é preciso comprovar empiricamente a posse e o uso. A fotografia, então, além de aproximar populações inteiras de uma prática cultural que lhes era anteriormente inacessível, é também reduzida a este papel: o de registrar as exibições espontâneas de uma multidão de dominados.

Então, há um mundo no qual as pessoas almejam adentrar. Um mundo habitado por alguns poucos privilegiados e virtualmente replicado por quem a ele nunca terá acesso. Daí a proliferação de imagens da vida cotidiana, transmutadas no uso de máscaras que atestam a vigência de um projeto de dominação. E todos os dias o mundo é tomado por fotografias que documentam o lazer, a culinária, a festa, os contatos sociais. Quanto ao trabalho, à dor e à miséria, estes são retratados, geralmente, para repercutir o trabalho, a dor e a miséria alheia. E não pense em encontrar, aqui, a alteridade. Ela nem sempre está presente, e sua ausência dificulta enormemente a expansão da consciência. Em Lefebvre (1991b) aprendemos que a consciência não é algo que tenha a ver tão somente com o sujeito que se pretende consciente, mas que é tomada de consciência acerca do outro. O processo de conscientização acontece quando deixamos de ser insensíveis às condições materiais de vida e ao sofrimento do outro. A consciência seria, então, consciência do outro, e não estou certa de que a mostra generalizada e excessiva de imagens do sofrimento alheio seria algo favorável à conscientização. Já vimos em Benjamin (1994) sobre a pobreza do excesso, e de como ele é impeditivo de que algo nos afete.

Das considerações tecidas até o momento, reconheço que escorre um certo fluido desagradável que lubrifica o pessimismo, mas os leitores que atentarem para o contexto histórico e político de escrita deste texto, provavelmente reconhecerão em seu entorno a mesma atmosfera (t)densa. Pudera eu convidar Pollyana para habitar um parágrafo, ou quem sabe um desses autores complacentes e, quem sabe, eles trariam uma pitada de otimismo, mas desde pequenina tenho o 
péssimo hábito de andar em más companhias e nunca demonstrei afeição por tais figuras felizes. Pois bem. Justificada a entonação do texto até este momento, vejamos um pouco sobre o artefato ao qual ele é dedicado: a fotografia.

Em seu livro Sociologia da fotografia e da imagem, José de Souza Martins (2008) nos presenteia com uma excelente conversação acerca do imensurável universo iconográfico. Tomando a fotografia enquanto referência, ele aborda dialeticamente aspectos contraditórios que a libertam de sua figuração secundária, passiva e fixa. Uma questão importante salientada pelo autor seria o fato de que o sujeito fotografado não é capturado pelas lentes do fotógrafo, mas que ele é protagonista na produção de sua imagem. Os aspectos decisórios se encontram em si, como por exemplo, o sorriso: se sorri ou não, se sorri aberta ou timidamente, se sorri ironicamente, ou ingênua, louca ou desvairadamente. Se há um fotógrafo direcionado por uma intenção, há também um fotografado que trava uma batalha vertiginosa e inteligente no sentido de definir como quer ser visto. Para Martins, ainda há quem se dedique a polarizar a fotografia enquanto objeto ou instrumento do conhecer, tomando-a por evidência ou aspecto metodológico. É preciso verificar o jogo de interações que se processa no momento infinitesimal de um clique, quando universos de significações se atravessam na batalha pela prevalência de um sentido - batalha inútil, posto que uma fotografia não dispõe da capacidade de determinar o que é, e ignora o que pode vir a ser.

Dentre tantas questões importantes oferecidas por Martins (2008), a segunda que destaco faz pensar a fotografia enquanto prática imersa na incerteza e na impossibilidade de circunscrição espaçotemporal: não é possível saber quando o desejo por um registro fotográfico surgiu, como este desejo direcionou a produção de uma imagem, como a realidade fotografada se via, o que escondia, o que considerou expor e quanto tempo e por quais espaços esta imagem continuará suscitando sentidos. Em geral, ignoramos tudo isso e acreditamos que a realidade possa ser capturada por nossas lentes, e que a fotografia seria a cópia fiel do que se passa. É absurdamente simples pensar assim, sobretudo quando se desconsidera que há inteligência nos deslocamentos do outro pelo mundo.

Junto a um sujeito que decide como se mostrar e à trepidação permanente causada pelas incertezas que atravessam os modos de produção da imagem, Martins (2008, p. 46) ressalta ainda a existência dos leitores de fotografia com seus infinitos modos de ler, desde os quais quem lê "[...] pratica um confisco visual da imagem, remontando-a, a partir de suas insuficiências, no seu próprio código de leitura que é também o manual sintético de suas experiências e das experiências do seu ver". Outro ponto a ser destacado no trabalho de Martins (2008), refere-se à negação da fotografia enquanto documento do cotidiano. A princípio restrita a uns poucos privilegiados devido ao alto custo envolvido na aquisição da câmera, filmes e revelação das imagens, é sabido que, atualmente, grande parte das pessoas fazem uso das fotografias digitais. Era de se esperar, portanto, que o registro da vastidão anônima da vida cotidiana estivesse em curso, mas não é a isso que Martins (2008) se refere. Ele observa o que se oculta enquanto se revela, os jogos de representação que as pessoas realizam quando se mostram para a sociedade. A foto registra o que se deseja dar a conhecer, disfarçando ou ocultando o que não se quer mostrar. Tanto o fotógrafo quanto o fotografado se encarregam desta tarefa de deturpação: o foco se desvia de uma parede caiada e se deposita sobre um canteiro em flor; as mãos sofridas e sujas são mantidas sob a mesa; pessoas ajuntadas produzem um sorriso especialmente para a foto, instantes antes de se afastarem. Há tutoriais que orientam sobre tudo isso, inclusive modos de produção do sorriso perfeito.

Revelação e ocultamento dizem respeito ao que as pessoas privilegiam expor e trazem em si o receio de serem consideradas pobres, feias, presentes em lugares sem prestígio ou no trabalho, acompanhadas por pessoas desprovidas de capital econômico e visibilidade social, justamente pela crença de que a pobreza é fruto da incapacidade pessoal, que a beleza humana dispõe de um padrão, 
que os lugares frequentados confirmam sua soberania no mundo, que o trabalho é inferior ao lazer e que as pessoas que nos cercam devem nos suprir com sua distinção social. Ao deturpar o que seria o registro de um acontecimento, fotógrafo e fotografado trazem "[...] dignidade à falta de dignidade, ao simplismo repetitivo da vida cotidiana. As pessoas se mostram representando, mas recorrem constantemente à fotografia para mostrar-se como terceira pessoa, a verdadeira, a que não está ali na cena, mas que está na foto” (MARTINS, 2008, p. 47).

Enfim, a fotografia não documenta o cotidiano. Ela capta identidades domingueiras as quais, para Martins (2008), se configuram na negação do trabalho. Se há alguém lavando a louça, esta atividade é rapidamente interrompida para que o corpo seja oferecido à lente da câmera; vassouras se quedam momentaneamente inertes; quem cozinha gira o corpo contra o fogão durante o registro fotográfico. Neste momento, nos deparamos com uma lógica segundo a qual seria preciso ocultar o trabalho e representar o ócio, uma lógica que informa ser preciso mostrar o distanciamento desta classe que trabalha, e o pertencimento à classe que usufrui - algo que garante às farturas serem

[...] vistas para serem legítimas, algo que permanece na cultura brasileira até hoje. Por isso mesmo, a transgressão no dar-se a ver, o fazer-se ver com a máscara do outro, do que domina, tem sido uma forma politicamente imperceptível de protesto social dos pobres. Uma espécie de inversão carnavalesca das identidades, uma inversão alegórica (MARTINS, 2008, p. 71).

Então... Se o fotógrafo não é isento de sua imaginação sociológica ao fotografar, se o fotografado representa no instante do registro, se a fotografia não documenta o cotidiano, e se a ocorrência da fotografia não cumpre roteiros previstos, nem tampouco espaçotempos planejados antecipadamente, o que resta da imagem, então? Bem, penso que continuamos a ter uma fotografia, um fotógrafo e um fotografado - apenas perdemos o controle. Ao perdermos o controle, cessamos as tentativas por capitalizar a imagem, por buscarmos enquadramentos estéticos, por obrigarmos a imagem a dizer aquilo que, em verdade, nós queremos dizer. Esta mecânica que forja na imagem o que de fato nós desejamos dizer é algo que está fortemente presente no trabalho de fotógrafos profissionais da miséria humana, aqueles que andam pelo mundo fotografando pretos, pobres, índios e refugiados, captando olhares que lampejam fome e desesperança, muitas vezes sem entender que estes olhos também olham. E para onde olham? Não sabemos, pois que as lentes estavam ocupadas em registrar o olhar do fotógrafo.

Mas este modo estranho e estrangeiro de olhar as coisas, desorientado mas verdadeiro, é o modo que crianças, camponeses, mulheres do povo, o povo ingênuo e simples olha. E eles têm medo do que veem (LEFEBVRE, 1991b, p. 20 - tradução nossa).

Infelizmente, o mercado está ávido por consumir a iconografia da miséria, até mesmo porque ter a foto do pobre na parede do escritório é algo que marca culturalmente a distinção de seu proprietário. É possível ainda que eu tenha me excedido na crítica, afinal, também precisamos da linguagem fotográfica do fotógrafo que registra o mundo de um ponto de vista político, estético, informativo e por diversas outras intencionalidades. Aqui, é importante buscar em Barthes (1984) algumas orientações que nos desvencilhem da ideia de que o fotógrafo, a fotografia ou o fotografado determinam o sentido, e prestar atenção ao que acontece na relação entre eles.

Para Barthes (1984), uma fotografia não pode ser classificada, ou seja, não é possível inserir uma imagem em alguma taxonomia que a especifique em seu caráter estético, crítico, político, informativo, doméstico ou outro qualquer. A arbitrariedade contida na classificação cristaliza um 
ponto de vista, fomentando uma forma específica de consumo. De modo a entender isso, e buscando na infinidade de imagens disponíveis na atualidade, vemos, por exemplo, as cidades históricas brasileiras. Na fotografia é possível admirar o belíssimo casario, o calçamento das ruas em pé-de-moleque, os lampiões nas calçadas, a arquitetura colonial. Trata-se de uma fotografia histórica, de um registro estético, da recordação de um turista ou da denúncia ao trabalho escravo empregado durante a construção da cidade? Mediada pelo atravessamento da interrogação reflexiva do observador, a imagem dirá algo. Uma classificação prévia não habilita a imagem a proferir verdades por si só. Ela apenas provoca. O que acontece não é proveniente de seu conteúdo, não jorra desde a imagem, mas acontece despretensiosamente no encontro com quem a observa.

Se não há uma classificação fixa, há, contudo, uma distinção. No mundo contemporâneo, o acesso às imagens ocorre excessiva e simultaneamente para quase todos nós, sendo que o olhar as percorre sem que pouco ou nada aconteça. Para Barthes (1984), trata-se de fotografias em que ocorre o studium. O studium é um campo descompromissado e não fecundo no qual as imagens são acompanhadas por códigos de leitura. Cada imagem é produzida para causar determinado efeito em uma grande população, momentaneamente. As pessoas não são capturadas pela imagem, mas pelas vantagens de adentrar o ruidoso debate que se forma em torno dela. Os observadores falam ao mesmo tempo sobre o mesmo - a imagem de hoje - e todos emitem opiniões. À noitinha, esta imagem entra em uma espécie de fade out effect, enquanto os que se envolveram em discussões sobre ela colhem os méritos efêmeros atribuídos a seus pontos de vista.

Embora disponha de força estética suficiente para ser observada, uma fotografia que integre o campo do studium não permanece para quem a observou. De certa forma isso nos protege, uma vez que não é possível dispensar atenção, o tempo todo, a um mundo predominantemente tomado por imagens. Heller (1970) ajuda a entender isso, quando trata das características que estruturam a vida cotidiana. Segundo ela, a profusão de acontecimentos que se processam ininterruptamente reforça a ultrageneralização e o economicismo, levando-nos a fazer uma espécie de seleção relacionada ao que iremos ver, e, do visto, o que iremos reparar para, reparando, pensar. Imagens do tipo studium são atravessadas por um olhar que já se conformou com seu desaparecimento. São belas, divertidas, dolorosas, instrutivas imagens que passam diante de nós, imagens natimortas cujo destino é o esquecimento. Curioso, isso: tradicionalmente considerada elemento por excelência a prestar serviço à memória, o destino de muitas imagens é tão somente o esquecimento.

Muitas fotos, infelizmente, permanecem inertes diante de meu olhar. Mas mesmo entre as que têm alguma existência a meus olhos, a maioria provoca em mim apenas um interesse geral e, se assim posso dizer, polido: nelas, nenhum punctum: agradam-me ou desagradam-me sem me pungir: estão investidas somente do studium (BARTHES, 1984, p. 48 - grifos do autor).

Raramente, contudo, uma imagem permanece. Não obstante o distanciamento espaçotemporal entre o observador e a fotografia, esta permanece. Ela permanece até mesmo após seu desaparecimento, continua a acontecer em quem a observou independentemente de quaisquer condições que sejam postas. Porque não é a fotografia em si que importa, mas aquilo que acontece entre ela e quem a observa. Algo acontece e se torna perene, e desde este momento, a imagem em si não mais importa. Peço a você, que me lê, a gentileza de interromper a leitura por um breve momento para retomar, mentalmente, uma imagem já vista. Esta imagem não se encontra à sua frente neste momento, talvez sua existência física já se tenha esgotado, mas ela permanece acontecendo em você e, surpreendentemente, o teor do que acontece em você, quando pensa nesta imagem, talvez nem esteja representado nela. 
Isto ocorre quando um detalhe, presente ou não na fotografia, se expande ao olhar: tratase do punctum, aquilo que "[...] acrescento à foto e que todavia já está nela" (BARTHES, 1984, p. 85 grifos do autor). Este detalhe é o que punge - o que fere, provoca, atormenta - e não se esquece. Barthes afirma que o punctum “[...] é um 'detalhe', ou seja, um objeto parcial. Assim, dar exemplos de punctum é, de certo modo, entregar-me" (BARTHES, 1984, p. 69 - grifos do autor).

É comum pensarmos que a entrega ocorre quando houve captura, mas nesse caso o aprisionamento não se refere à privação do que quer que seja. O punctum instala no pensamento um detalhe que supomos ter encontrado na fotografia, enquanto o liberta de qualquer codificação prévia. O observador se entrega a pensar sobre a foto e a desejar compreender o detalhe que o capturou, num esforço contraditoriamente voluntário se considerar que "[...] essa foto trabalhou em mim, e mais tarde compreendi [...]" (BARTHES, 1984, p. 83). O que se compreende com o punctum não se encontra, necessariamente, na fotografia, portanto, um exame minucioso não oferece serventia: "[...] no fundo - ou no limite - para ver bem uma foto mais vale erguer a cabeça ou fechar os olhos" (BARTHES, 1984, p. 84). Talvez você tenha fechado os olhos, caso tenha retomado uma imagem que foi punctum em você, instantes atrás. Trabalhar com o punctum de uma fotografia requer o movimento dialético de olhar para algo no interior do qual não irá encontrar o elemento perturbador que the aconteceu ali. Onde se esconde este elemento? $\mathrm{Na}$ fotografia? Em você? Ou na relação entre a fotografia e você? É perturbador pensar que desde este objeto visível, "[...] seja o que for o que ela dê a ver e qualquer que seja a maneira, uma foto é sempre invisível: não é ela que vemos" (BARTHES, 1984, p. 16).

Pois bem. Influenciada pelas excelentes contribuições oferecidas por Martins (2008) e Barthes (1984), há algum tempo tenho me interessado pela fotografia e, muito especialmente, por aquilo em que ela me ajuda a pensar em Educação. É preciso concordar com Barthes: são raros, estes momentos. É preciso concordar também com Martins: são imprevisíveis. No encontro com uma imagem, as fronteiras disciplinares se rompem, desvelando para o observador não aquilo que é observável na fotografia, mas o que ele inventa, segundo o que lhe interessa. Para mim, que me interesso por Educação, minhas andanças pelo mundo (fisicamente restrito entre duas cidades pequenas e a roça) são atravessadas por surpreendentes aprendizagens. A inventividade das pessoas comuns está presente na vida cotidiana, expressa em objetos, linguagens, práticas e em quaisquer outras criações humanas. Estas pequenas invenções são fruto da necessidade, mediadas pela produção de conhecimentos compartilhados e, em geral, irrelevantes no âmbito de perspectivas científicas e econômicas. Pois todas estas inventividades do fraco (CERTEAU, 1994) que se imiscuem em cotidianos me interessam, motivo pelo qual eu as tenho registrado em imagens.

Neste artigo, apresento três destas imagens. Com elas, algo se expandiu, afetando minha compreensão sobre a escola, sobre a educação popular, sobre a permanência das injustiças sociais em um mundo que poderia ser lindo. Estas imagens foram produzidas ao acaso, no momento em que condições ótimas se atravessaram. Não são, portanto, parte de um projeto desde o qual a pesquisadora saiu em busca de algo, e por terem sido produzidas isentas de método, estas imagens nunca se curvaram ao que eu desejava dizer. Isso faz lembrar Boaventura Santos (2002a, p. 66) ao ensinar que "[...] cada método é uma linguagem e a realidade responde na língua em que é perguntada". A imagem faz dissipar o método, quando se trata do campo do punctum. Uma imagem que provoque a produção de conhecimentos não pode ser planejada - ela acontece. E não acontece 
devido a um desejo ingênuo e positivista de que aconteça, mas pela crença ${ }^{2}$ de que, mediadas por suas condições materiais de vida, as pessoas produzem sua existência.

As imagens apresentadas não foram produzidas no interior de instituições de ensino, não foram planejadas e não dispõem de quaisquer relações diretas com a Educação. Elas são fruto do acaso, rompem as fronteiras disciplinares e pressupõem que o conhecimento é analógico (SANTOS, 2002a). Muito tempo tem sido despendido com a intenção de aproximar as disciplinas. Bastante louvável em seus propósitos, a ideia da interdisciplinaridade visa fomentar o diálogo entre conhecimentos estanques. Um problema neste propósito foi o reducionismo presente em sua transposição didática, quando houve um esforço por aproximar as disciplinas, em detrimento de aproximar as pessoas. Não são as disciplinas que dialogam, são as pessoas. A matemática jamais falará a linguagem da filosofia, isso porque suas sofisticadíssimas particularidades delineadas através dos séculos não podem ser justapostas em um projeto escolar ou impostas por um currículo prescrito. A aproximação disciplinar, portanto, não ocorre através da aproximação das disciplinas, mas das pessoas. Ela acontece quando alguém que tenha refinado seus conhecimentos em determinada área, dialoga com outro alguém que fez o mesmo em outra direção, e então ambos se ouvem e se encantam mutuamente, observando o que lhes afetou e - muito importante - criando outra coisa a partir daquilo. Tenho um exemplo.

Sou licenciada em Letras, e todos estão cientes de que a formação inicial influencia fortemente nossas percepções sobre o mundo. Recentemente, assisti à palestra de um físico que dissertava sobre astronomia, particularmente sobre o nascimento das estrelas. Ouvia a tudo com bastante atenção, mas esta não era direcionada a compreender o que ele dizia. Dificilmente eu compreenderia, pois faltavam a mim anos de instrução específica. Minha atenção era direcionada a ouvir o que acontecia em mim, enquanto eu o ouvia. Lembro especialmente de um momento em que ele disse que as "estrelas brilham e piscam" porque estão vivas: esta faiscação seria o resultado físico de energia jorrando da estrela, comprovando sua existência. Fiquei a pensar nisso, mas agora pensando na beleza de um ser que, enquanto permanece vivo, jorra. Isso me levou até Certeau, e a quase visualizar as pessoas caminhando pelo mundo a jorrar linguagens, práticas, saberes, emoções tão somente porque estão vivas. A Física e as Letras se mantiveram distantes durante este saboroso momento: quem se moveu fui eu, tecendo um outro saber inclassificável e provavelmente fadado a desaparecer, pois que o mundo não se interessa por invencionices que não podem ser controladas.

Através das imagens, passei a compreender isso. A imagem é inclassificável, já vimos em Barthes (1984). Ela pode abranger tudo, ao mesmo tempo em que provoca a criação de tudo. A imagem seria cenário delimitado por moldura, mas isento de fronteiras; seria constituída por determinado conteúdo, mas desprovida de um sentido único; produzida para dizer algo, enquanto provoca o observador a dizer o que acontece em si. Imagem é feito estrela que jorra.

\section{NO MORRO, NO MURO, NO ASFALTO}

Por alguns instantes me detive para decidir se as imagens com as quais pretendia dialogar neste texto seriam ou não reproduzidas aqui, e neste momento de escrita, adianto que a resposta é não. Uma fotografia que nos acontece enquanto punctum dispensa a exigência de exibição, pois não faz parte da categoria de imagens que se prestam à comprovação empírica ou à ilustração do que se diz. Isto porque não é o que está registrado na imagem o que nos interessa, mas o que se passa

\footnotetext{
2 Aqui é importante deixar claro que a crença a que me refiro não é proveniente de um plano religioso, mas tem a ver com uma epistemologia que legitima a existência política do outro. Crer implica em acreditar que o outro atribui sentidos e força política ao que faz. Aprendi sobre isso com um padre, Michel de Certeau (1994).
} 
com aquele que a observa. Isto posto, apresento três imagens que fiz em três momentos distintos, e que, conforme vimos em Barthes (1984), continuam a trabalhar em mim.

A primeira delas, uma escadaria escavada em um morro, a partir de um banco escavado na terra do mesmo morro. Eu passava por uma estrada vicinal, na área rural, quando me deparei com um morro no qual havia vários buracos sequenciais escavados na terra, constituindo uma escada que dava acesso ao cume. A escada iniciava em um banco. Este banco também havia sido escavado na terra e se conectava à escada que conduzia ao topo do morro, com uma extensão aproximada de 30 metros. Cada degrau aparentava ter a dimensão para acolher um pé de uma pessoa adulta, e a inclinação do morro oferecia alguma segurança para quem o subisse. No alto do morro, nada. Não havia nenhuma edificação, ou mata, ou cultivo. Era somente o alto do morro, e mais nada.

Fiquei a pensar nos sentidos daquilo. Por que alguém escavaria uma escada para ter acesso ao alto de um morro onde encontraria tão somente o sol escaldante sobre a pele? A escada luzia ao sol, indício do uso constante de seus degraus. Movida pela curiosidade, fotografei a escada e o banco. Um morador do lugar, então, me disse do que se tratava. Os trabalhadores rurais daquela comunidade tiveram acesso, recentemente, ao uso de smartphones e internet. Após diversas tentativas para usarem os aparelhos, descobriram que o melhor lugar para se conectar era o alto do morro. Reunidos por um propósito comum escavaram a escada e, todas as tardes, após a lida, era possível ver um grupo de jovens sentado no alto do morro, enquanto o sol se punha e era substituído pelas telas dos aparelhos na tarefa de iluminar o rosto de cada um. As rodas de conversas que aconteciam rés ao chão, no banco escavado na terra, foram substituídas por encontros silenciosos em um lugar anteriormente improvável para eles.

A segunda imagem aconteceu no pátio de uma escola na qual eu me encontrava, acompanhada por algumas orientandas, para desenvolver pesquisa sobre alfabetização. Neste dia permanecemos com a professora e seus alunos em classe, e foi no intervalo do recreio que aconteceu. Sentada no pátio com as orientandas, observávamos os movimentos das crianças. Um desses movimentos, bastante frequente, era direcionado ao muro lateral da escola. Vez ou outra, uma criança se encaminhava para lá. Neste muro, havia um buraco. Um buraco no muro da escola? Sim. O buraco estava situado a aproximadamente um metro e meio do chão, e suas dimensões provavelmente configuravam um quadrado de 30 x 30 centímetros. Uma janelinha, se melhor lhe apetece. Fora da escola, do outro lado da rua, havia uma quitanda. Pois bastava um menino se aproximar do muro que em poucos instantes o vendeiro se aproximava trazendo o quitute solicitado. E não vinha somente o menino: professoras e funcionárias da escola também faziam uso do prestimoso vão providencialmente criado na cercania institucional. Através do buraco do muro passavam salgadinhos, doces, refrigerantes, pipocas e iguarias afins, os quais eram devidamente pagos com dinheiro contado, ou a despesa era escrita na caderneta para pagar depois.

Não ouvimos nenhuma alteração no tom de voz dos envolvidos no pequeno comércio. Havia ali um conhecimento tácito e compartilhado por todos acerca do que estava à disposição na venda e seus respectivos preços, bem como havia, por parte do vendeiro, a leitura certeira daquilo que o comprador avistado através do buraco desejava adquirir. Dada a natureza instituinte da operação, prevalecia uma atmosfera honesta que dispensava conflitos e indisposições.

Terceira imagem. Observe que, assim como foi com a primeira e com a segunda, esta imagem também me aconteceu durante um percurso. Caminhando pela vida cotidiana, eu a inventei. A partir do registro que fiz com a câmera fotográfica, a imagem passou a acontecer em mim. Eu transitava também por uma estrada, a BR 356, nas proximidades do distrito de Pirapanema, em Muriaé/Minas Gerais. Nesta estrada sinuosa e com elevações constantes, há um trecho plano e linear no qual os motoristas costumam exceder o limite de velocidade. De um lado e do outro deste trecho, há uma pequena comunidade que clamava há tempos pela instalação de 
redutores de velocidade no local. O menino sai da escola que fica do lado de lá, e precisa atravessar a pista. A mãe se apavora. Todo dia. Não era possível que a vida já tão sofrida fosse acrescida por esta ameaça permanente.

Após constatarem o que já sabiam - que o poder público não tomaria providências - os habitantes decidiram, eles mesmos, se protegerem do perigo iminente. Construíram dois quebramolas na reta, acompanhados por placas de sinalização adequadas, confeccionadas por eles mesmos. As placas sinalizavam a presença dos quebra-molas a 100 e 50 metros, foram produzidas com pedaços de lata reutilizados, pintados e fixados em suportes de madeira. Os quebra-molas foram construídos com pedras de mão e cimento, e desde então os corações das mães voltaram ao ritmo usual.

O conteúdo das imagens as constitui fisicamente, e tão logo cumpra a tarefa de registrar o que morre diante de $\mathrm{si}^{3}$, a fotografia continua a existir secundariamente. Ao mesmo tempo em que seu registro é preservado em sua trama iconográfica, ela também se dá nos atravessamentos de concepções que não se restringem aos limites observáveis de seus traços. A imagem é uma linguagem a dizer algo que não precisa ser encontrado nela. Enquanto renitentemente se esquiva da tarefa de reprodução do mundo, fogosamente se entrega à atividade criadora que ocorre na relação com o observador.

Diferentes entre si, as fotografias do morro, do muro e do asfalto aproximam o observador do universo de lutas das classes populares pela própria existência. Elas ampliam rizomas de sentidos que se movem lucidamente em meio às condições materiais de vida de sujeitos comuns, dando a ver os movimentos anônimos empreendidos por quem é alijado dos direitos sociais e do usufruto dos bens de consumo coletivo. As três imagens retratam eventos cotidianos que não têm força para serem considerados importantes e isso é bastante curioso, pois são eventos que, em sua ocorrência, demandaram a aproximação de pessoas que dispunham de um mesmo interesse ou problema. Estas pessoas, aproximadas por algo em comum, inventaram modos inteligentes de se organizar, enunciaram a questão entre si, criaram alternativas escolhendo a que lhes pareceu mais apropriada, distribuíram as tarefas para a execução da solução e, por fim, compartilharam o resultado de todo este trabalho. Silenciosamente.

Todo este movimento silencioso e anônimo que acontece o tempo todo, por toda a parte, é perseguido por mecanismos introduzidos pelos dominantes, objetivando a manutenção desse silêncio e anonimato. O que seria do projeto de dominação capitalista se fossem notadas as sofisticadíssimas formas de atuação na realidade, empreendidas pelas classes populares? É sabido que, vez ou outra, uma delas escapa das nuvens do apagamento, e, quando isso acontece, é rapidamente transformada em folclore ou caricatura. Neste momento, as criações coletivas projetadas no morro, no muro e no asfalto são reduzidas a constructos risíveis - "olha só que graça, o pessoal daqui fez um quebra-molas, uma escada, um buraco no muro" - diriam os que riem de barriga cheia.

Essa aparente redução não anula o que há de grande na obra observada, mas dificulta a fermentação necessária à criticidade de quem a interpreta. A inteligência, solidariedade, consciência e trabalho coletivo presentes durante a percepção do problema, bem como sua solução, se expandem desde a historicidade da imagem. Isto não pode ser anulado e - repito - está presente o tempo todo, por toda a parte, na vida cotidiana. Enquanto a competição, a acumulação, o

\footnotetext{
${ }^{3}$ Cf. em Barthes (1984, p. 20), que trata dessa “[...] coisa um pouco terrível que há em toda fotografia: o retorno do morto" e na afirmação de Martins (2008, p. 28) quando diz que “[...] a fotografia nega-se enquanto suposição de retrato morto da coisa viva, porque é, sobretudo, retrato vivo da coisa morta. A fotografia aprisiona e 'mata' o fotografado, pessoas e coisas. E ao mesmo tempo torna-se coisa viva nos usos substitutivos que adquire."
} 
individualismo e a arrogância constituem o ator político dominante que burocratiza a cotidianidade (LEFEBVRE, 1991), ideiaspráticas tais como a justiça, a cooperação, a alteridade, o diálogo e o compartilhamento nutrem a força política do cotidiano. Como esta força é possível a todos nós que somos pessoas comuns, entendemos por que a vida cotidiana é menosprezada pelos protagonistas dos projetos de dominação. A menorização da vida cotidiana é um projeto continuamente executado pelo fato de que, se o cotidiano pode ser programado de forma a incutir a alienação, é também ele, o cotidiano, o palco para mudar a vida (LEFEBVRE, 1991b).

Nas imagens do muro, do morro e do asfalto os praticantes não foram registrados, assim como não foi registrada a miséria do cotidiano com sua homogeneidade, fragmentação e hierarquização inscritas pela modernidade (LEFEBVRE, 1991b). Diferente disso, são imagens que relatam rupturas com a imposição ou privação de algo e provocam a reflexão acerca da vida enquanto obra de arte, mediada por desejos coletivos. Esta provocação, contudo, não é direcionada a um fim específico e nem dispõe de quaisquer aspectos prescritivos, pois que acontece na relação entre o observador e a imagem. Esta, completamente desprovida de aparatos estéticos, expande-se em miríades de sentidos quando complementada por quem se entrega a inventar outras coisas com o que vê.

Enfim, a intenção nesta escrita não foi, especificamente, a mostra de morros, muros e asfaltos. Eu poderia ter mostrado imagens de praças, pontes, fiações elétricas, encanamentos hidráulicos, pichações, e meu movimento seria o mesmo: olhar a fotografia para ver o que não está ali. Acontece que nosso olhar tende a ser descritivo e obediente, vemos um buraco no muro e só vemos o buraco no muro mesmo ${ }^{4}$, para, a seguir, difamar o buraco, "mas que absurdo isso que fizeram! Um buraco no muro da escola, quem fez isso? É depredação de patrimônio público, eu faço a minha parte, temos que denunciar, só pode ser coisa de bandido, e aquela escadaria insana até o topo do morro, não tô falando? Essa gente da roça tem cada uma! São uns jecas ignorantes, por isso não conseguem nada na vida, sei bem como é essa gente, por exemplo, olha lá aquele quebra-molas na estrada, que coisa monstruosa, esse povo pensa que é quem para fazer isso? Pensa que é gente? Cimento no asfalto? E essas placas então? Vamos ligar para as autoridades competentes, vamos denunciar isso aí, somos cidadãos de bem”- diriam exatamente estes, os cidadãos de bem.

\section{BREVÍSSIMA CONCLUSÃO}

Mudei de ideia. Antes de partir, deixo as imagens aqui para você. Não que eu tenha qualquer pretensão de que elas lhe digam algo, nem tampouco que sejam apreciadas esteticamente ou que comprovem a veracidade do que foi escrito. Estas imagens não se prestam a nada disso. Deixo as imagens aqui porque vou-me embora e você ficará só.

Até breve.

De resto, as fotos, salvo no cerimonial forçado de algumas reuniões tediosas, devem ser olhadas quando se está só. Suporto mal a projeção privada de um filme (não há público suficiente, não há anonimato suficiente), mas tenho necessidade de estar sozinho diante das fotos que olho (BARTHES, 1984, p. 145).

Figura 1: A escadaria no morro e o antigo banco

\footnotetext{
4 Aprendemos com Adélia Prado.
} 

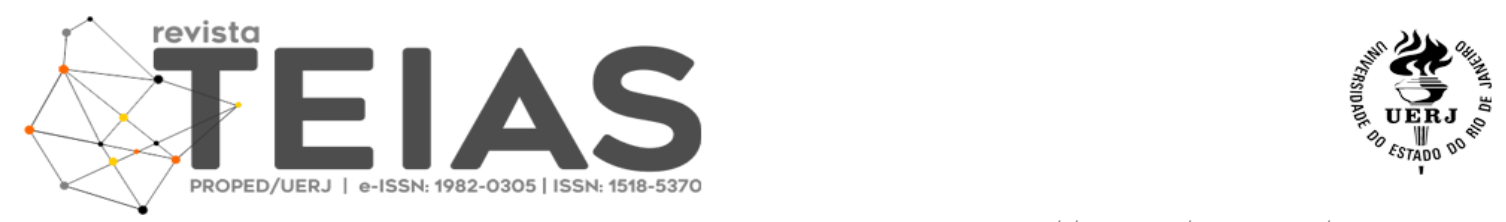

DOI: https://doi.org/10.12957/teias.2020.48636

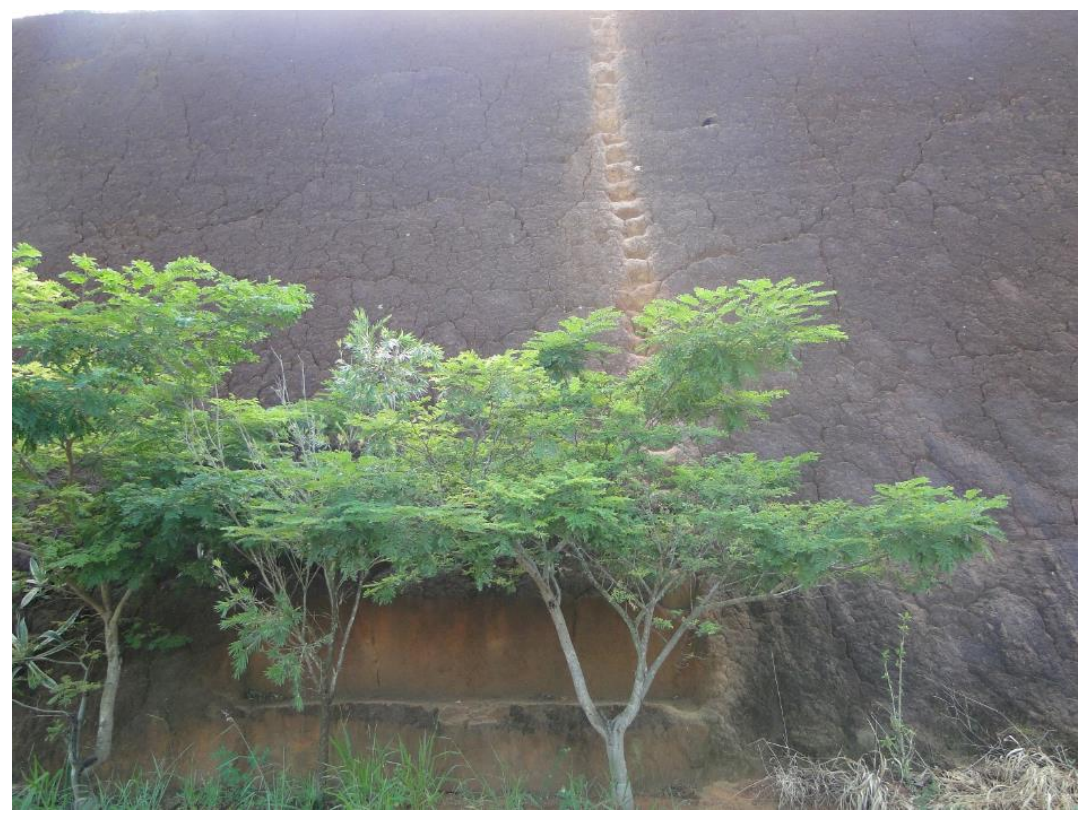

Fonte: arquivo pessoal, 2018

Figura 2: O buraco no muro da escola

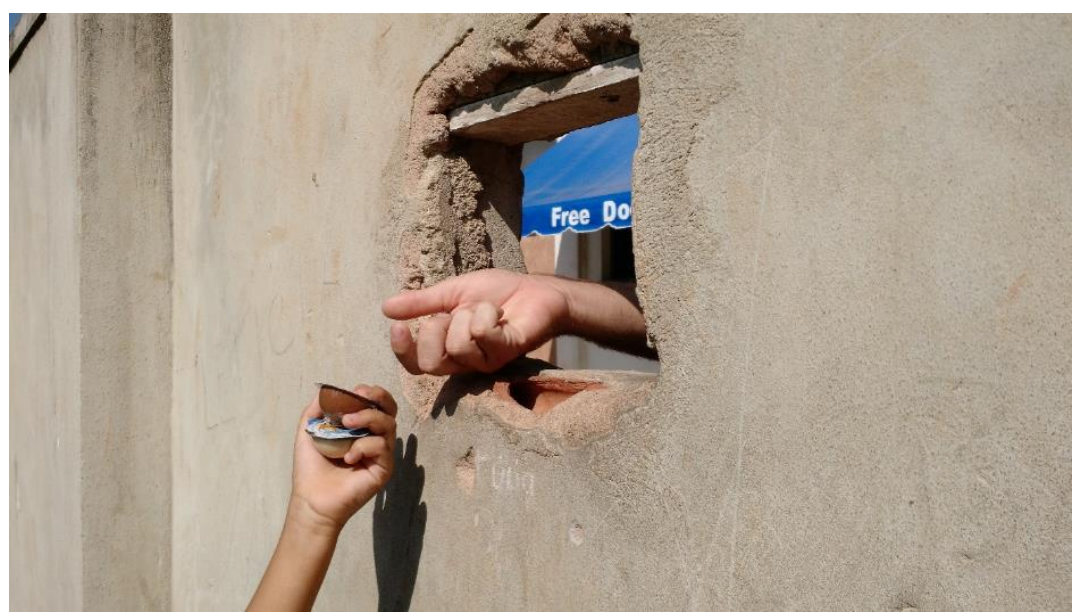

Fonte: arquivo pessoal, 2016

Figura 3: O quebra-molas de cimento no asfalto

Revista Teias v. 21 • n. 60 • jan./mar. 2020 • Sessão Especial Redes Educativas e mediações digitais: tensões e insurgências 


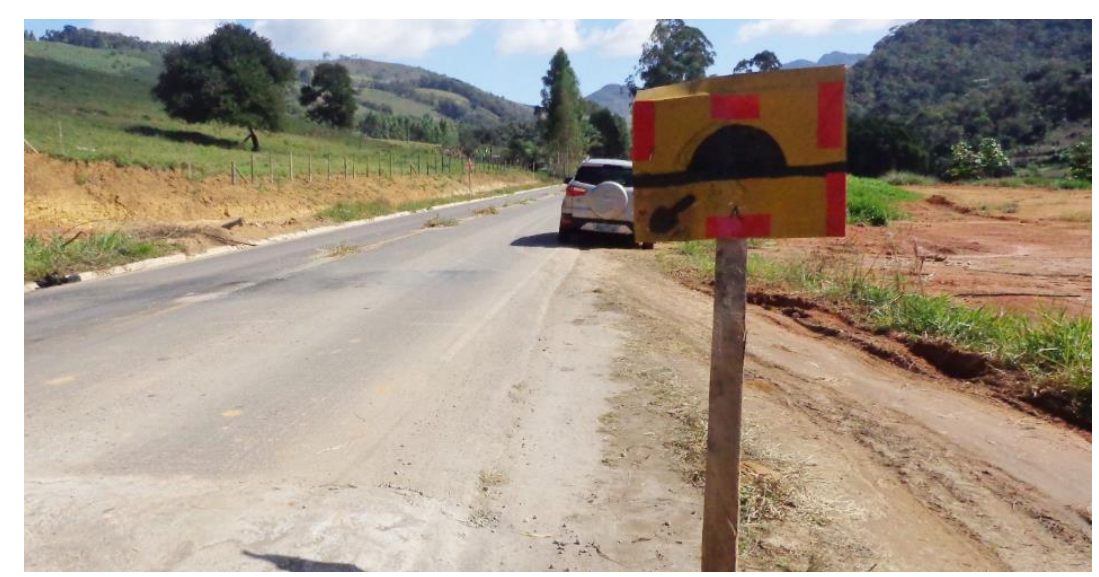

Fonte: arquivo pessoal, 2015

\section{REFERÊNCIAS}

BENJ AMIN, Walter. O narrador. Considerações sobre a obra de Nikolai Leskov. In: Magia e técnica, arte e política. São Paulo: Brasiliense, 1994.

BARTHES, Roland. A câmara clara: nota sobre a fotografia. Rio de Janeiro: Nova Fronteira, 1984.

CERTEAU, Michel de. A invenção do cotidiano. Artes de fazer. Petrópolis: Vozes, 1994.

HELLER, Agnes. O cotidiano e a história. Rio de Janeiro: Paz e Terra, 1970

LACERDA, Mitsi Pinheiro de. A alfabetização e o alfabetizar. Revista Imagens da Educação, Londrina, vol. 5, n. 1, p. 46-56, 2015. Disponível em http://twixar.me/TxXT. Acesso em 11/02/2019.

LEFEBVRE, Henri. Perspectivas da Sociologia Rural. In: MARTINS, José de Souza. Introducão crítica à Sociologia Rural. São Paulo: Hucitec, 1986.

LEFEBVRE, Henri. A vida cotidiana no mundo moderno. São Paulo: Ática, 1991a.

LEFEBVRE, Henri. Critique of everyday life. v. I. Introduction. London: Verso, $1991 \mathrm{~b}$.

LEFEBVRE, Henri. A produção do espaço. Trad. Pereira, D. B. e Martins, S. (do original La production de l'espace). Paris: Éditions Anthropos, 2000. Disponível em http://grupogpect.info/2014/06/02/livro-a-producao-do-espaco-de-henri-Lefebvre . Acesso em 15 set. 2016.

MARTINS, José de Souza. O poder do atraso. Ensaios de Sociologia da História Lenta. São Paulo: Hucitec, 1994.

MARTINS, José de Souza. Sociologia da fotografia e da imagem. São Paulo: Contexto, 2008.

SANTOS, Boaventura de Sousa. Um discurso sobre as ciências. Porto: Edições Afrontamento, 2002a.

SANTOS, Boaventura de Sousa. Para uma sociologia das ausências e uma sociologia das emergências. Coimbra. Revista Crítica de Ciências Sociais, 63, out./2002b, p. 237-280. 
DOI: https://doi.org/10.12957/teias.2020.48636

\section{Informações da autora}

Mitsi Pinheiro de Lacerda

Professora Associada do Departamento de Ciências Humanas e do Programa de Pós-Graduação em Ensino da Universidade Federal Fluminense (UFF).

E-mail: mitsipinheiro@id.uff.br

ORCID: http://orcid.org/0000-0003-2552-0590

Link Lattes: http://lattes.cnpq.br/867285948281426

Revista Teias v. 21 • n. 60 • jan./mar. 2020 • Sessão Especial Redes Educativas e mediações digitais: tensões e insurgências 